\title{
Strategic Factors of Teacher's Commitment in Salatiga
}

\author{
Wahyu Tri Astuti' ${ }^{1}$, Tri Joko Raharjo ${ }^{2}$, Haryono ${ }^{3}$, Suwito Eko Pramono ${ }^{4}$ \\ ${ }_{1,2,3,4}$ Graduate School, Universitas Negeri Semarang-Jawa Tengah, Indonesia \\ Corresponding email: wahyu_sltg@yahoo.com
}

\begin{abstract}
The aim of the research is to analyze the direct influence of teachers' ethic and teachers' performance toward teachers' commitments. Research method used is quantitative method which is using Krejcie table as the sample of the research. There are 172 of Civil Servant Teachers (PNS) of Public High School in Salatiga, and in the Krejcie table there are 118 samples. The data collection is conducted by instruments which are being tested and reliable for exogenous teachers' ethic variable, excellent service, and endogenous teachers' commitments variable. The research result: (1) The teachers' ethic variable proved that it did not directly affect to the teachers' performance variable; (2) the teachers' ethic variable had significant effect to the teachers' commitment directly, (3) the excellent service variable had significant effect to the teachers' commitment variable.The Authenticity: The result of the research helps the teachers to improve their commitments to optimally manage the school effectively and efficientl.
\end{abstract}

Keywords: Teachers, Ethic, Excellent Service, and Teachers’ Commitment.

\section{Introduction}

Education is a magnificent world which has the aim to magnify the children of the nation. On the other side, education is also complicated since it contains of many aspects which are related such as the aim, the learners, the lecturers, the learning materials, the learning infrastructures, learning methods and media, and also the assessment system. More, Education could be described as a large spectrum world which is various and could be seen in its lines and stages. Therefore it will not be exaggerating if the implementation education problems could not be classified obviously as it causes difficulties to develop education's quality itself. In fact, National Education System which is on UndangUndang No. 20 Tahun 2003 tends not to solve the education problems appropriately, effectively, and efficiently.

Regarding the function and the aim of national education, every educational unit has its duty and aim which is more specific. High School (SMA) is one of educational institution which is part of National Education system aims to develop students' potentials to be religious human to God, magnificent though, healthy, capable, creative, independent, and to be national citizen who has responsible and democratic. By running the activities, SMA holds the continuation education for graduated students of Middle School Level (SMP) to have knowledge, attitude, and skill which are needed in university level. Based on that reason, the essential value of SMA is the learning process, where the teacher becomes human sources (SDM) which determines the success of learning process.

According to the explanation above, so learning as the education implementation is not only interaction process between learner and lecturer and/ or learning sources on certain environment, but it is more on cognition process and internalization so the learners will get additional concept and knowledge and also they can develop the proper attitude and behavior correctly. Based on those reasons, the education implementation should be done correctly so the education aim could be reached.

The management system of education implementation becomes the basic need, it also becomes a problem which needs to be recited and analyzed accurately so the education aim could be reached optimally. This tough is based on its reality that education is a complex world which is wide and has various spectrums on it. So, the management system should be developed based on education management including the knowledge itself and the art. Education management is combination of activities which is an effort of management process by a group of people in organization of education who aim to reach the education aims which are stated effectively and efficiently. Brandt and Teija Laitinen (2016) with 53,7 \% respondent result report that the service is not given correclt and clearly, and the staff low service ability. Management of Education is a collective activity about human teamwork 
process which is membered in the education organization in order to achieve education purpose that is made effectively and efficiently.

Education management is combination of activities which is an effort of management process by a group of people in organization of education who aim to reach the education aims which are stated effectively and efficiently. The effectiveness and the efficiencies of education management will be depended by the accuracy of consideration and analyzation of education aspects such as human resources, the management of supporting sources, and movement management (Everard dan Geoffrey Morris, 2004). The three aspects will bring into narrow consideration such as leadership (transformational leadership of the principle), culture, capabilities, commitment (teachers' commitments), work ethic (teachers' ethic), performance (teachers' performance), satisfaction (satisfaction of teachers' work), belief, ethics, motivation, infrastructures, cost, achievement, learners, potentials, and environment.

Teacher who becomes a central component of education system at school should have strong commitment to work. More by having strong commitment, a high teacher' performances could be conducted optimally. If the tough could be conducted, the hope of materialization of national education aims under teachers' responsibilities will be far to be reached. This tough contains that the hope to develop nation and country is not possible to be real. Based on those toughs above, it is necessary to conduct some considerations regarding some factors or variables which are estimated give significant contributions toward teachers' commitments in theirs school organizations.

Talking about teachers' commitments toward their school organizations, there are some estimated factors affect them which are internal factors and external factors. Steers in Williams \& Hazer (1996: 220) stated there are some factors influence the commitments: (1) the individual characteristics which want some better changes, ages, and education; (2) working experiences and the effect to socialize in their works as become one connection to connect group attitude to the organization way and self-work perception about things permitted in the organization. (3) work characteristics, including work challenges, the opportunity to have social interaction and the feedback. Steers placed the possibility of commitment's effect above the work characteristics.

Based on those concepts above, they could be classified as: (1) internal factors such as: work motivation (commitment), preference, talent, work satisfaction, individual characteristics, emotional exhaustion, individual role in some dimensions (service performance), work ethic (teachers' ethics), and more; (2) external factors such as: workplace environment or family circles, workplace environment (infrastructures), the culture of school organization, organization climates, leadership style of the leader (transformational leadership), and more. From this study there are some factors developed which are organization commitments factors such as, teachers' ethics and teachers' performances.

Teachers' ethics concept as God's mercy: (1) a teacher believes that his/her teacher's life is conducted by God's mercy which he/she should act and live honestly and sincerely as the knowledge supplier, moral model, and the skill guidance; (2) a teacher who is conscious that he/she is not the vital knowledge sources, but he/she is only as the distributors to distributes knowledge and skill; (3) a teacher who has commission will do the tasks properly.

Teachers' ethics concept as commission (Sinamo, 2016: 42) to (1) believe the selfcompetencies as commission and able to do his/her job as the professional standard technic given; (2) have high integrity and able to do his/her job as the moral standard given, also keep clear from Corruption Collusion Nepotism $(\mathrm{CCN})$.

Teachers' ethics concept as service-giver that teaches properly who have a low-profile mindset. This indicates that a teacher' attitudes as: (1) technically a teacher should teach beyond school's capability; (2) work based on high mutual standard on common professionalism technics. Teachers' ethics could be measured on the the sub-concept (1) teachers' ethics as God's mercy; (2) teachers' ethics as commission; (3) teachers 'ethics as service. The results study from Ainna etc. (2016) said that the high quality school is related to high quality service. The increase of this quality that is given by school undirectly can improve student loyality. 
Excellent service is literal meaning which means the best service-giver or excellent. It is called as excellent or best because it is based on the standard service which occurs or have the service-giver department. If we relate the excellent service and public service, both means giving the excellent service to the citizens and becomes realization of civil servant' responsibilities. The considerations of the experts indicate that it is important to give excellent service to the customers by developing Total Quality Service (TQS) concept.

Those toughs are get along with which are: reliability, which is related to the corporate's ability to deliver the accurate service as shown by teacher's excellent service at the first time; (2) responsiveness, it is related to the ability to service provider to help the customers and to respond their needs immediately; (3) assurance, it is related to the knowledge and the respected employee who could develop trust feeling and confidence of the customers; (4) empathy, it means the company is able to know the customer's problems and act for customer's sake and also have convenient office hour; (5) tangibles, it is related to the physical appearance of the service facilities, the equipment, human resources, and the company communication materials.

Organizational commitments or loyalties of work is the stages of work which the employee identifies him/herself to which organization they belongs to and want to continue actively participate in it (Wibowo, 2016: 430). Schermerhorn, Hut, Osborn, and Uhl-Bien (2011: 72) in (Wibowo, 2016: 430) introduced two kind of organizational commitments; there are rational commitment and emotional commitment. Rational commitment indicates his/her feeling that their jobs fulfill the financial interest, development, and their professions. Otherwise, emotional commitment reflects that things he/she has done are important, valuable, and give benefits for others. Organizational commitment in an organizational commitment, an employee identifies an organization, the aim, and also the expectation to be the part of the group (Robbins and Judge, 2015: 47).

According to Meyer and Allen (1991) organizational commitment is a psychological condition which (a) indicates the relationship between employee and the organization, and (b) has implication toward the decision to continue or to quit from his/her membership. In other words, the desire of the member to stay or to quit from the organization can be determined from how deep he/she feels toward his/her organization.

Teacher's work commitment is an association between him/her to his/her duty given consciously as a teacher and could provide responsibilities which direct and guide in learning process. A high teacher's work commitment is needed in school organization to make high commitment and influence a professional work situation. Talking about teacher's work commitment, there are two things could not be separated which are loyalty followed by commitment. Teacher's commitment in delivering knowledge, energy, and also tough toward students is important things in order to reach the aim of education. As school resources, teachers should have high commitment to perform their functions as lecturers who have dedications.

Based on those reasons above, it is necessary to consider about some factors which might have strong contribution toward organizational commitment (the commitment of teacher's performance). It is important because of the consistency of teachers' commitments toward the school giving direct effect toward the quality process and the education result, which also influence on developing vision and mission of national education as well as the vision and mission of Ministry of Education and Culture to develop Indonesians who are smart and competitive.

\section{Methods}

The research method used in this study is research design which uses correlational survey. Based on the problems which are conducted in this study, the design of the study used to identify the data from the sample taken from the population, and to describe the relationship between variables. Creawell (2015) stated the research survey is a procedure of quantitative research which the researcher conduct surveys on a sample or in a population of people to describe attitudes, opinions, behaviors, or certain characteristics population (Creswell, 2015: 752). Correlation is statistical experiment to determine tendency for two variables or more or two set data for various consistent. 
The variable of the study contain teacher's ethic, excellent service, and teacher's commitment. The variables in this study use casual model, which should be classified to be exogenous and endogenous variables. The subjects of the study conducted are civil servant teachers (PNS teachers) of public high school (SMA Negeri) in Salatiga. The populations of PNS teachers of SMA Negeri in Salatiga are 172. While sample is part of the amount and characteristics which own by those populations (Sugiyono, 2014: 149). The sample used in this study use Krejcie table. The teacher populations of SMA Negeri in Salatiga which are 172, based on Krecie table the sample of the study are 118 teachers. The technic which used in this study is Structural Equation Modeling (SEM) which conducted by using AMOS 24.0 programe. The formula constructed as:

\section{Endogenous Variable $=$ Exogenous Variable + Endogenous Variable + Error \\ The Similarity of Structural$$
\text { Commitment }=\beta_{1} \text { Teacher's Ethic }+\gamma_{1}
$$$$
\text { Excellent Service }+\mathbf{z} 1
$$

The experiment of compatible model based on the criteria (goodness of fit). The experiment by using fit index conducted to measure "validity" of model. Reliability is the measurement of the internal consistency from construct's indicators that show the degree to in every indicator which indicates a construct/ latent factors which are general. The unidimesionality experiment needs to be conducted in every multi-indicator constructs before the reliability being assigned. The phenomenological use is to assign Composite Reliability and Variance Extracted in every constructs (Ferdinand, 2014).

\section{Results and Discussion}

Teacher's ethic is latent variable which assigned by using three dimensions and its indicators. The calculation of mean score in every variable's dimension of teachers ethic by the use of three indicators shown that X2 indicator about teacher's ethic as commission becomes indicator which have highest score of mean which means the respondent have working ethich and also working spirit as teachers and perform with honest, responsible, sincere feeling. While in $\mathrm{X} 3$ indicator, about teacher's ethic as service-giver could be perception that has the lowest score. The measurement of excellent service conducted by adopting the indicators which is used in the previous reseach. The result of descriptive analyzing by using the score of frequency answers, mean, and deviation standard of the frequency answers result, reeata, and deviation standard in every indicator. From the calculation above shown that $\mathrm{X} 4$ indicator becomes indicator which have the highest mean score. While on X7 indicator, becomes indicator which might have the lowest score. The measurement of commitment variable conducuted by adopting the indicators from the previous study. The result of descriptive analyzing by using the score of frequency answers, mean, and deviation standard of the frequency answers result, mean, and deviation standard in every indicator. As the result, it shows that X9 indicator abot affectiveness (career, sense of belonging, sense of assosiated, family member) has the highest mean score while X10 indicator of normative value (moral value of organization, benefits for others, guiltiness, in debt with organization) become indicator which have lowest score of the smallest mean.

In assigning the research model there are two stages of analyzing conducted, there are confirmatory analysis and experiment analysis of research model.

The Hypothesis Assignment, the assignment of the three hypotheses which conducted in this study by analyzing the score of Critical Ratio (CR) and the probabilities of the causalities relation. (1) The assignment of Teacher's Ethic toward Excellent Service, CR calculation $(1,305)<\mathrm{CR}$ table $(2,000)$ and the probability score $(0,192)>0,05$ so it can be concluded that teacher's ethic variable could not directly affect toward excellent service; (2) The Assignment of the Effect of Teacher's Ethic toward Teacher's Commitment, CR calculation $(2,711)>\mathrm{CR}$ table $(2,000)$ and the probability score $(0,007)<0,05$ so it can be concluded that the teacher's ethic variable significantly affect toward teacher's commitment; (3) The Assignment of the Effect of Excellent Service toward Teacher's Commitment, CR calculation $(6,344)>\mathrm{CR}$ table $(2,000)$ and probability score $(0,000)<$ 0,05 so it can be concluded that the excellent service significantly affect the teacher's commitment. 
The Assignment of Hypothesis 1, the hypothesis zero can be accepted and the alternative hypothesis can be rejected. The H1 is being rejected and can be concluded that teacher's ethic did not directly affect the excellent service. As the result, Hypothesis 1 cannot be proven; The Assignment of Hypothesis 2, hypothesis zero can be rejected and alternative hypothesis can be accepted. The $\mathrm{H} 2$ can be accepted because teacher's ethic directly affects the teacher's commitment. As the result, the hypothesis 2 can be proven; The Assignment of Hypothesis 3 , hypothesis zero can be rejected and alternative hypothesis can be accepted. The H3 is accepted and can be concluded that excellent service directly affect the teacher' commitment. As the result, the hypothesis 3 can be proven.

\section{Conclusion}

The study conducted as the way to assign in how to improve PNS teacher's commitment on teacher's ethic and excellent service. From the study conducted, it could solve the research's problems significantly in how to improve teacher's commitment by teacher's ethic and excellent service. However in this study could answer the problems in the public school, the civil servant teachers (PNS teachers) do not have good teacher' ethic to be good service-givers so they do not have motivation to service properly because they got the payment and the service users come by themselves. The study found that the lowness of teacher's ethic supported by the low level of excellent service PNS teachers in Salatiga. Also, it is found that teacher's ethic and excellent service directly affect toward the PNS teachers' commitment in Salatiga.

\section{References}

Allen, N.J., and Meyer, J.P. 1991. A Three Component Conceptualization of
Organizational Commitment, Human Resource Management Review, Volume 1 , Number1.

1990. The measurement and antecedents of affective, continuance, and normative commitment to organization. Journal of occupational psychology.

Ainna,, Nurul., Pramono, Suwito Eko., dan Subagyo. (2016). " Pengaruh Kualitas Layanan, Citra Sekolah, dan Keupasan Siswa terhadap Loyalitas Siswa", Jurnal Manajen Pendidikan Unnes, Vol 5, hal 2

Creswell, John. 2015. Riset Pendidikan Perencanaan, Pelaksanaan, Dan Evaluasi Riset Kualitatif Dan Kuantitatif. Yogyakarta: Pustaka Pelajar.

Donaldson, S.I., E.A., \&Grant-Vallone,E.J. 2000. Longitudinal Examination of Mentoring Relationships on Organization Commitment and Citizen Behavior. Journal of Career Development, 26,233-249.

Everard K.B, Geoffrey Morris. Ian Wilson. 2004. Effective School Management. Paul Chapman Publishing.

Ferdinand, Augusty. 2014. Metode Penelitian Manajemen.

Semarang: Badan Penerbit Universitas Diponegoro.

Sinamo, Jansen. 2016. 8 Etos Keguruan. Jakarta: Esensi Erlangga.

Steers, R.M and Porter, R.W. 1983. Motivation and Work Behavior. Edisi ke-3 New York: Mc

Khodijah, Nyanyu (2013) "Performance of Madrasah Teachers and PostCertification Islamic Religious Education Teachers in South Sumatra". Cakrawala Pendidikan Journal, $\quad$ Vol 32(1). 